\title{
Faktor Risiko Kanker Serviks di Rumah Sakit Umum Pemerintah Dr. Wahidin Sudirohusodo Makassar, Sulawesi Selatan
}

\author{
Risk Factor of Cervical Cancer in Dr. Wahidin Sudirohusodo Government \\ General Hospital Makassar, South Sulawesi
}

\author{
Sri Syatriani
}

Peminatan Epidemiologi Sekolah Tinggi Ilmu Kesehatan Makassar

\begin{abstract}
Abstrak
Kanker serviks adalah tumor ganas terbanyak pada perempuan di seluruh dunia termasuk Indonesia. Jumlah penderita kanker serviks di Rumah Sakit Umum Pemerintah Dr. Wahidin Sudirohusodo pada tahun 2007 sebanyak 231 kasus, menurun menjadi 220 kasus tahun 2008 dan menurun sebanyak 167 kasus pada tahun 2009. Tujuan penelitian ini adalah untuk melihat besar risiko kejadian kanker serviks terhadap penggunaan pembalut, penggunaan sabun, status ekonomi, dan pasangan pria yang tidak disirkumsisi. Jenis penelitian adalah penelitian observasional analitik dengan desain kasus kontrol. Sampel adalah pasien yang berkunjung ke bagian ginekologi yang diambil secara accidental sampling sebanyak 213 orang. Pengumpulan data dilakukan dengan wawancara menggunakan kuesioner. Hasil penelitian dengan analisis OR menunjukkan bahwa penggunaan pembalut yang berkualitas rendah $(\mathrm{OR}=2,320)$, penggunaan sabun $\mathrm{pH}>4(\mathrm{OR}$ $=2,360)$, status sosial ekonomi $(\mathrm{OR}=4,087)$, dan pasangan pria yang tidak disirkumsisi $(O R=2,092)$ merupakan faktor risiko kejadian kanker serviks. Kata kunci: Kanker serviks, pembalut, sabun, status sirkumsisi
\end{abstract}

\footnotetext{
Abstract

Cervical cancer is the most malignant tumor in women in the world particularly in developing countries including Indonesia. In 2007, the number of cervical cancer patients in Dr. Wahidin Sudirohusodo Government General Hospital were 231 cases, declined to 220 in 2008 and further declined to 167 cases in 2009. The aim of this study is to discover the risk of cervical cancer associated with the use of pads, the use of soap, economic status, and male partners who are not circumcised. The design of this study is a case control. Samples are randomly taken from 213 gynecological patients. Data was collected by interview through the use of a questionnaire. Results of research with analysis of OR showed that the use of low-quality pads (OR $=2,320)$, the use of soap $\mathrm{pH}>4(\mathrm{OR}=2,360)$, socioeconomic status (OR $=4,087)$, and male partners who are not circumcised $(O R=2,092)$ are the risk factors for cervical cancer.
}

Key words: Cervical cancer, pad, soap, circumcised status

\section{Pendahuluan}

Kanker serviks adalah kanker yang terjadi pada serviks uterus, suatu daerah pada organ reproduksi wanita yang merupakan pintu masuk ke arah rahim yang terletak antara rahim (uterus) dengan liang senggama (vagina). Kanker ini biasanya terjadi pada wanita yang telah berumur, tetapi bukti statistik menunjukkan bahwa kanker serviks dapat juga menyerang wanita yang berumur antara 20-30 tahun. ${ }^{1}$ Selain kanker payudara, kanker serviks merupakan salah satu dari 2 jenis kanker yang banyak membunuh kaum perempuan di Indonesia. Menurut penelitian World Health Organization (WHO), di seluruh dunia terdapat 490.000 kasus kanker serviks dan mengakibatkan 240.000 kematian tiap tahunnya, $80 \%$ dari angka itu terjadi di Asia. Berdasarkan penelitian, sebesar $25,6 \%$ dari 10 jenis kanker pada perempuan adalah kanker serviks, sedangkan $73 \%$ dari 3.874 pasien kanker yang ada merupakan kanker pada kelamin perempuan. Seluruh dunia, setiap 1 menit terdapat $1 \mathrm{ka}-$ sus baru dan setiap 2 menit terdapat 1 kematian.

Kejadian kanker serviks dipengaruhi oleh berbagai faktor, antara lain faktor sosio demografi yang meliputi usia, status sosial ekonomi, dan faktor aktivitas seksual yang meliputi usia pertama kali melakukan hubungan seks, pasangan seks yang berganti-ganti, paritas, kurang menjaga kebersihan genital, merokok, riwayat penyakit

Alamat Korespondensi: Sri Syatriani, Peminatan Epidemiologi Sekolah Tinggi Ilmu Kesehatan, Jl. Maccini Raya No. 197 Makassar, Hp. 08124122230, e-mail: ssyatriani@gmail.com 
kelamin, trauma kronis pada serviks, penggunaan pembalut serta penggunaan kontrasepsi oral dalam jangka waktu lama lebih dari 4 tahun. ${ }^{2}$

Menurut Dinas Kesehatan Sulawesi Selatan, kasus kanker serviks di Sulawesi Selatan tahun 2008 sebanyak 573 kasus. ${ }^{3}$ Penderita kanker serviks di Rumah Sakit Umum Pemerintah (RSUP) Dr. Wahidin Sudirohusodo cenderung menurun, akan tetapi penurunannya tidak signifikan dimana pada tahun 2007 sebanyak 231 kasus, menurun pada tahun 2008 yaitu sebanyak 220 kasus, dan pada tahun 2009 sebanyak 167 kasus. ${ }^{4}$ Tujuan penelitian untuk melihat besar risiko kejadian kanker serviks terhadap penggunaan pembalut, penggunaan sabun, status ekonomi, dan pasangan pria yang tidak disirkumsisi.

\section{Metode}

Jenis penelitian ini adalah penelitian observasional dengan pendekatan case control study untuk mengetahui faktor risiko higiene perorangan (penggunaan sabun dan penggunaan pembalut), status ekonomi, pasangan pria yang tidak disirkumsisi. Penelitian dilaksanakan pada bulan Februari-Maret tahun 2010. Populasi dalam penelitian ini adalah semua pasien yang berkunjung ke bagian ginekologi di RSUP Dr. Wahidin Sudirohusodo periode 2010. Sampel dibagi dalam 2 kelompok. Kasus adalah semua pasien yang berkunjung ke bagian ginekologi yang dinyatakan menderita kanker serviks. Kontrol adalah semua pasien yang berkunjung di bagian ginekologi yang dinyatakan tidak menderita kanker serviks. Sampel diambil dengan menggunakan teknik accidental sampling yaitu dengan mengambil kasus atau responden yang kebetulan ada atau tersedia pada saat penelitian berlangsung. Data yang dikumpulkan adalah data primer berupa penggunaan pembalut, penggunaan sabun, status ekonomi serta pasangan pria yang tidak disirkumsisi dengan melakukan wawancara kepada responden menggunakan kuesioner.

Penggunaan pembalut dibedakan risiko rendah untuk responden yang menggunakan dan sering mengganti pembalut ketika menstruasi serta risiko tinggi untuk responden yang menggunakan pembalut atau kain dalam waktu yang lama. Penggunaan sabun dinyatakan berisiko rendah apabila menggunakan sabun pencuci vagina dengan $\mathrm{pH}=4$ tidak setiap hari, berisiko tinggi apabila menggunakan sabun pencuci vagina dengan $\mathrm{pH}>4$ atau sabun lain seperti sabun mandi atau deterjen. Standar sabun pencuci vagina yang baik memiliki $\mathrm{pH}=4$ karena $\mathrm{pH}>4$ akan membunuh bakteri di vagina. ${ }^{5}$ Pendapatan berisiko rendah apabila pendapatan keluarga $\geq \mathrm{Rp}$. 1.000 .000 setiap bulan dan risiko tinggi apabila pendapatan keluarga $<$ Rp. 1.000 .000 setiap bulan, sesuai standar upah minimum di Provinsi Sulawesi Selatan. Sirkumsisi dibedakan berisiko rendah apabila responden mempunyai pasangan pria yang sudah disirkumsisi dan berisiko tinggi apabila responden memiliki pasangan pria yang tidak disirkumsisi. Sirkumsisi dapat menjadi faktor risiko kanker serviks karena smegma yang terdapat pada prepusium laki-laki yang tidak disirkumsisi akan menjadi tempat berkumpulnya bakteri dan virus yang ketika berhubungan seksual akan menularkan ke pasangan seksnya. ${ }^{6}$

\section{Hasil}

\section{Karakteristik Variabel Penelitian}

Sebagian besar umur responden pada kelompok kasus dan kontrol sama, yaitu 41-50 tahun $(39,44 \%)$ dan $(28,17 \%)$. Status perkawinan responden pada kelompok kasus dan kontrol sebagian besar kawin, masing-masing $92,96 \%$ dan $79,58 \%$. Sebagian besar pekerjaan responden pada kelompok kasus dan kontrol juga sama, yaitu ibu rumah tangga, masing-masing $88,73 \%$ dan $61,97 \%$. Pendidikan responden pada kelompok kasus sebagian besar tamat SMA $(46,48 \%)$ dan sebagian besar responden pada kelompok kontrol tamat SMA $(40,85 \%)$ (Lihat Tabel 1).

Sebagian besar kelompok kasus menggunakan pembalut yang berisiko tinggi $(66,2 \%)$ dan sebagian besar kelompok kontrol menggunakan pembalut risiko rendah $(54,2 \%)$. Penggunaan sabun sebagian besar kelompok kasus menggunakan sabun dengan $\mathrm{pH}>4(62 \%)$ dan sebagian besar kelompok kontrol menggunakan sabun dengan $\mathrm{pH} \leq 4(59,2 \%)$. Sebagian besar kelompok kasus mempunyai pendapatan $\leq$ Rp. $1.000 .000(66,2 \%)$ dan sebagian besar kelompok kontrol mempunyai pendapa$\tan >$ Rp. 1.000 .000 (67,6\%). Sebagian besar kelompok kasus dan kelompok kontrol memiliki pasangan pria yang disirkumsisi sebesar 91,5\% untuk kasus dan 95,8\% untuk kontrol (Lihat Tabel 2).

\section{Analisis Bivariat}

Wanita yang menggunakan pembalut risiko tinggi berisiko 2,3 kali lebih besar untuk menderita kanker serviks dibanding wanita yang menggunakan pembalut risiko rendah. Wanita yang menggunakan sabun dengan $\mathrm{pH}>$ 4 berisiko 2,4 kali lebih besar untuk menderita kanker serviks dibanding wanita yang menggunakan sabun dengan $\mathrm{pH} \leq 4$. Wanita dengan pendapatan $\leq \mathrm{Rp}$. 1.000.000 berisiko 4,1 kali lebih besar untuk menderita kanker serviks dibanding wanita dengan pendapatan > Rp. 1.000.000. Wanita yang memiliki pasangan pria tidak disirkumsisi berisiko 2,1 kali lebih besar untuk menderita kanker serviks dibanding wanita yang memiliki pasangan pria yang disirkumsisi (Lihat Tabel 3).

\section{Pembahasan}

Kanker serviks menyerang wanita yang pernah atau sekarang aktif secara seksual. Biasanya kanker ini 
Tabel 1. Karakteristik Responden

\begin{tabular}{|c|c|c|c|c|c|}
\hline \multirow{2}{*}{ Variabel } & \multirow{2}{*}{ Kategori } & \multicolumn{2}{|c|}{ Kasus } & \multicolumn{2}{|c|}{ Kontrol } \\
\hline & & $\mathbf{n}$ & $\%$ & $\mathbf{n}$ & $\%$ \\
\hline \multirow[t]{7}{*}{ Umur } & $11-20$ & 0 & 0 & 5 & 3,52 \\
\hline & $21-30$ & 3 & 4,23 & 28 & 19,72 \\
\hline & $31-40$ & 17 & 23,94 & 33 & 23,24 \\
\hline & $41-50$ & 28 & 39,44 & 40 & 28,17 \\
\hline & $51-60$ & 20 & 28,16 & 24 & 16,90 \\
\hline & $61-70$ & 3 & 4,23 & 10 & 7,04 \\
\hline & $>70$ & 0 & 0 & 2 & 1,41 \\
\hline \multirow[t]{3}{*}{ Status perkawinan } & Belum kawin & 2 & 2,82 & 15 & 10,56 \\
\hline & Kawin & 66 & 92,96 & 113 & 79,58 \\
\hline & Janda & 3 & 4,22 & 14 & 9,86 \\
\hline \multirow[t]{5}{*}{ Pekerjaan } & Tidak bekerja & 2 & 2,82 & 28 & 19,72 \\
\hline & Ibu rumah tangga & 63 & 88,73 & 88 & 61,97 \\
\hline & Wiraswasta & 4 & 5,63 & 11 & 7,75 \\
\hline & PNS & 2 & 2,82 & 10 & 7,04 \\
\hline & Karyawan swasta & 0 & 0 & 5 & 3,52 \\
\hline \multirow[t]{5}{*}{ Pendidikan } & Tidak sekolah & 2 & 2,82 & 0 & 0 \\
\hline & Tamat SD & 15 & 21,13 & 20 & 14,08 \\
\hline & Tamat SMP & 33 & 46,48 & 45 & 31,69 \\
\hline & Tamat SMA & 16 & 22,54 & 58 & 40,85 \\
\hline & Tamat PT & 5 & 7,04 & 19 & 13,38 \\
\hline
\end{tabular}

menyerang wanita yang telah berumur, terutama pada wanita yang berusia 35-55 tahun. Namun tidak mustahil wanita yang lebih muda dapat menderita penyakit ini jika mempunyai faktor risikonya. Wanita yang aktif secara seksual pada usia 20-35 tahun dan terinfeksi oleh Human Papilloma Virus (HPV) akan menderita kanker serviks dalam periode waktu 10-20 tahun. ${ }^{7}$ Wanita yang menikah sebelum berusia 20 tahun berisiko terkena kanker serviks karena pada usia tersebut organ seksual belum siap untuk hubungan seksual pada usia dini. ${ }^{8}$

Akan tetapi, terlambat menikah juga merupakan faktor risiko kanker serviks karena golongan wanita ini akan terus-menerus mengalami ovulasi tanpa jeda sehingga rangsangan terhadap endometrium terjadi terusmenerus sehingga dapat membuat sel-sel endometrium berubah sifat menjadi kanker.

\section{Pembalut Wanita}

Pembalut wanita merupakan benda yang sangat vital bahkan telah menjadi kebutuhan pokok bagi kaum hawa ketika sedang menstruasi. Tanpa disadari, justru menjadi salah satu faktor risiko penyakit kewanitaan akibat kandungan zat dioxin yang menurut WHO dapat menyebabkan kanker. Risiko penggunaan pembalut wanita untuk menderita kanker serviks disebabkan oleh kandungan dioxin dan serat sintetis. Semua merupakan faktor risiko bagi kesehatan wanita, termasuk kanker serviks, endometriosis, infertilitas, dan kanker ovarium. Kongres Amerika H.R. 890 tahun 1999 menyatakan bahwa zat dioxin dan serat sintetis ditemukan pada pembalut wanita dan produk sejenis yang lain berisiko tinggi terhadap kesehatan wanita, termasuk risiko kanker serviks, endometriosis, kanker rahim, kanker payudara, kesuburan, dan penurunan sistem kekebalan tubuh. ${ }^{9}$

Zat dioxin dapat meresap ke dalam rahim apabila darah haid jatuh ke atas permukaan pembalut wanita yang akan dilepaskan melalui proses penguapan. Pembalut yang mengandung zat dioxin bercampur darah menstruasi yang tidak steril menyentuh permukaan vagina akan dihisap ke dalam rahim. Selanjutnya bersama aliran darah terbawa menuju ke organ-organ tubuh yang lain. Pertama, akan mengenai permukaan vagina/vulva, diserap ke dalam rahim melalui saluran serviks, selanjutnya masuk ke dalam uterus, berikutnya melalui tuba fallopi dan berakhir di ovarium. Itulah sebabnya, pembalut wanita yang menjadi sahabat wanita ketika haid berpotensi memicu berbagai masalah pada organ kewanitaan. 10

Salah satu penyebab wanita terjangkit infeksi vagina antara lain penggunaan pembalut yang tidak berkualitas. Kebanyakan produsen pembalut wanita menggunakan bahan-bahan kimia berbahaya yang dapat mengakibatkan berbagai penyakit pada sistem reproduksi wanita, seperti dismenorea (menstruasi yang sakit). Pembalut adalah produk sekali pakai sehingga para produsen mendaur ulang bahan baku kertas pulp dan menjadikannya bahan dasar untuk menghemat biaya produksi. Banyak bahan kimia yang digunakan dalam proses daur ulang untuk 
Tabel 2. Distribusi Faktor Risiko Kanker Serviks Menurut Kelompok Kasus dan Kontrol

\begin{tabular}{llllll}
\hline \multirow{2}{*}{ Variabel } & Kategori & \multicolumn{2}{c}{ Kasus } & \multicolumn{2}{c}{ Kontrol } \\
\cline { 3 - 6 } & & $\mathbf{n}$ & $\%$ & $\mathbf{n}$ & $\%$ \\
\hline \multirow{2}{*}{ Penggunaan pembalut } & Risiko tinggi & 47 & 66,2 & 65 & 45,8 \\
Penggunaan sabun & Risiko rendah & 24 & 33,8 & 77 & 54,2 \\
Pendapatan & Risiko tinggi $(\mathrm{pH}>4)$ & 44 & 62 & 58 & 40,8 \\
& Risiko rendah $(\mathrm{pH} \leq 4)$ & 27 & 38 & 84 & 59,2 \\
Pasangan pria tidak disirkumsisi & $\leq$ Rp. 1.000.000 & 47 & 66,2 & 46 & 32,4 \\
& $>$ Rp.1.000.000 & 24 & 33,8 & 96 & 67,6 \\
& Ya & 6 & 8,5 & 6 & 4,2 \\
& Tidak & 65 & 91,5 & 136 & 95,8 \\
\hline
\end{tabular}

Tabel 3. Faktor Risiko Kanker Serviks

\begin{tabular}{llcc}
\hline Variabel & Kategori & OR & 95 \% CI OR \\
\hline Penggunaan pembalut & $\begin{array}{l}\text { Risiko tinggi } \\
\text { Risiko rendah } \\
\mathrm{pH}>4\end{array}$ & 2,32 & $1,28-4,19$ \\
Penggunaan sabun & $\begin{array}{l}\mathrm{pH} \leq 4 \\
\leq \mathrm{Rp} .1 .000 .000 \\
\text { Pendapatan }\end{array}$ & 2,36 & $1,31-4,23$ \\
Sirkumsisi & $\begin{array}{l}\text { Ya } 1.000 .000 \\
\text { Tidak }\end{array}$ & 2,09 & $23-7,48$ \\
& & & $0,65-6,74$ \\
& & &
\end{tabular}

proses sterilisasi pada kertas bekas dan pemutih sehingga banyak mengandung zat dioxin yang lebih berbahaya seperti arsinekum. Dioxin mempercepat proses perkembangan semua jenis kanker, khususnya pada wanita. Kondisi ini menyebabkan gangguan terhadap organ reproduksi wanita. ${ }^{9}$

\section{Penggunaan Sabun}

Kebiasaan mencuci vagina dengan antiseptik berupa obat cuci vagina dan deodoran untuk menjaga kebersihan dan kesehatan vagina atau alasan lain dapat meningkatkan risiko kanker serviks. ${ }^{11}$ Menurut hasil penelitian yang dilakukan didapatkan bahwa $48 \%$ responden menggunakan sabun biasa dengan kadar $\mathrm{pH}>4$, bahkan ada yang menggunakan deterjen untuk mencuci organ kewanitaan mereka. Pemilihan cairan pembersih juga harus diperhatikan dengan memilih pembersih khusus area kewanitaan yang kadar $\mathrm{pH}$-nya 3-4 dan ada izin dari Departemen Kesehatan. Hindari pembersih kewanitaan dengan kadar $\mathrm{pH}$ yang tinggi karena akan mengakibatkan kulit kelamin menjadi keriput dan mematikan bakteri yang mendiami vagina. ${ }^{5}$ Iritasi yang berlebihan dan terlalu sering dapat merangsang perubahan sel yang berakhir dengan kejadian kanker. Pencucian vagina menggunakan bahan kimia dengan kadar $\mathrm{pH}$ yang tidak cocok sebaiknya tidak dilakukan secara rutin, kecuali ji- ka ada indikasi misalnya infeksi yang memerlukan pencucian dengan zat-zat kimia yang disarankan dokter. Pembersih tersebut dapat membunuh kuman termasuk Bacillus doderlain di vagina yang memproduksi asam laktat untuk mempertahankan $\mathrm{pH}$ vagina. ${ }^{12}$

Menurut hasil penelitian yang dilakukan oleh Islamiyah di Rumah Sakit Umum Daerah Dr. Soetomo Surabaya tahun 2008 menunjukkan bahwa kebersihan pribadi dalam hal tidak menggunakan sabun khusus vagina untuk membersihkan vagina berhubungan dengan kejadian kanker serviks $(p=0,00$ dan $O R=6,070) .13$

\section{Penghasilan}

Kanker serviks banyak ditemukan pada golongan masyarakat berpenghasilan rendah. Faktor pendapatan berkaitan dengan dengan gizi dan imunitas. Golongan pendapatan rendah umumnya memiliki kuantitas dan kualitas makanan kurang dan hal ini mempengaruhi imunitas tubuh. Studi deskriptif dan analitik memperlihatkan hubungan yang kuat antara kejadian kanker serviks dengan tingkat sosial ekonomi yang rendah. Hal ini juga diperkuat dengan infeksi HPV yang lebih tinggi di kalangan wanita berpendidikan dan berpenghasilan rendah. ${ }^{14}$ Kelompok berpenghasilan rendah biasanya kurang terakses dengan pelayanan kesehatan yang berkualitas termasuk pemeriksaan pap smear yang seharus- 
nya dilakukan para wanita berusia 35 tahun keatas. Wanita berpenghasilan rendah biasanya tidak memperhatikan status gizi dan imunitas. Penghasilan sangat berpengaruh terhadap kejadian kanker serviks. Para wanita berpenghasilan rendah tidak mampu membeli pembalut wanita yang berkualitas tinggi atau sabun pencuci vagina yang aman bagi kesehatan. Berdasarkan aspek kebersihan individu, para ibu yang berpenghasilan rendah tersebut pasti sulit menerapkan kebersihan individu yang aman.

Menurut Teheru, 15 dan Hidayati, 16 terdapat hubungan antara kanker serviks dengan penghasilan, dimana wanita yang berpenghasilan rendah 4 kali lebih berisiko dibanding wanita yang berpenghasilan tinggi. Penghasilan rendah biasanya dikaitkan dengan higiene, sanitasi, dan pemeliharaan kesehatan yang kurang. ${ }^{17}$

\section{Pasangan Pria yang Tidak Disirkumsisi}

Sirkumsisi adalah tindakan medis berupa pembuangan sebagian atau seluruh bagian prepusium yang melingkupi kepala penis. Pasangan pria yang tidak disirkumsisi dapat meningkatkan risiko kanker serviks. ${ }^{18}$ Infeksi HPV pada penis ditemukan pada 166 orang dari 847 laki-laki yang tidak disirkumsisi (19,6\%), lebih tinggi daripada yang disirkumsisi (16 dari 292 laki-laki yang disirkumsisi). Sirkumsisi menurunkan risiko kanker serviks pada pasangan karena menurunkan risiko infeksi HPV pada penis. ${ }^{19}$ Laki-laki yang tidak melakukan sirkumsisi dapat meningkatkan risiko seorang wanita untuk terkena kanker serviks melalui mekanisme yang diduga berasal dari smegma yang terdapat pada prepusium laki-laki. ${ }^{12}$ Kelenjar subacea yang memproduksi smegma terdapat pada lapisan dalam prepusium. Cairan ini berguna untuk melumasi permukaan prepusium. Letak kelenjar ini di dekat pertemuan prepusium dan glans penis yang membentuk semacam "lembah" di bawah korona glans penis (bagian kepala penis yang berdiameter paling lebar). "Lembah" ini merupakan tempat berkumpulnya keringat, debris/kotoran, sel mati, dan bakteri. Apabila pria disirkumsisi, kotoran ini mudah dibersihkan. ${ }^{19}$ Hasil yang berbeda didapatkan oleh Khasbiyah tahun 2004 di Rumah Sakit dr. Kariadi Semarang yang menunjukkan bahwa sirkumsisi pasangan seksual tidak berhubungan dengan kanker serviks. ${ }^{20}$

\section{Kesimpulan}

Penelitian menemukan bahwa wanita yang menggunakan pembalut ketika menstruasi dan tidak sering diganti berisiko 2,3 kali lebih besar menderita kanker serviks. Selain itu, wanita yang menggunakan sabun dengan $\mathrm{pH}>4$ berisiko 2,4 kali lebih besar untuk menderita kanker serviks. Wanita yang tingkat penda- patannya rendah dan memiliki pasangan yang tidak disirkumsisi memiliki risiko 4,1 kali lebih besar dan 2,1 kali lebih besar untuk menderita kanker serviks.

\section{Saran}

Perlu penyuluhan yang intensif kepada para wanita tentang pentingnya menggunakan pembalut yang berkualitas tinggi dan aman bagi kesehatan. Sebaiknya wanita memilih sabun pencuci vagina yang $\mathrm{pH}$-nya $\leq 4$ dan pemakaiannya jangan terlalu sering. Sebaiknya wanita yang tingkat pendapatannya rendah lebih memperhatikan kebersihan organ kewanitaannya. Selain itu, wanita yang pasangan prianya tidak disirkumsisi dianjurkan untuk disirkumsisi.

\section{Daftar Pustaka}

1. Diananda R. Mengenal seluk-beluk kanker. Jogjakarta: Kata Hati; 2007.

2. De Jong W. Kanker, apakah itu? pengobatan, harapan hidup, dan dukungan keluarga. Jakarta: Arcan; 2004.

3. Dinas Kesehatan Provinsi Sulawesi Selatan. Profil kesehatan Sulawesi Selatan. Makassar: Dinas Kesehatan Provinsi Sulawesi Selatan; 2008.

4. Rumah Sakit Umum Pemerintah Dr. Wahidin Sudirohusodo. Rekam medik RSUP Dr. Wahidin Sudirohusudo. Makassar: RSUP Dr. Wahidin Sudirohusodo; 2009.

5. Pramulyas R. Panduan praktis jaga kebersihan area kewanitaan. 2009. [diakses tanggal 6 Februari 2010]. Diunduh dari: http://re.email@yahoo.com.

6. Pradipta B. Penggunaan vaksin human papilloma virus dalam pencegahan kanker serviks. Jakarta: Fakultas Kedokteran Universitas Indonesia; 2007.

7. Bustan MN. Epidemiologi penyakit tidak menular. Jakarta: PT Rineka Cipta; 2007.

8. Brunner S. Keperawatan medikal bedah. Jakarta: EGC; 2001.

9. Majid F. Sejam satu wanita meninggal karena kanker serviks. [diakses tanggal 5 Februari 2010]. Diunduh dari: http://www.tribuntimur.com.

10. Ath-Huri H. Bahaya pembalut wanita dan cara pengetesan kualitas. [diakses tanggal 20 Mei 2011]. Diunduh dari: http://www.google.com.

11. Rabe T. Buku saku ilmu kandungan. Jakarta: Hipokrates; 2003.

12. Purnomo H. Pencegahan dan pengobatan penyakit yang paling mematikan. Yogyakarta: Buana Pustaka; 2009.

13. Islamiyah A. Faktor yang berhubungan dengan terjadinya kanker serviks di RSUD Dr. Soetomo Surabaya. [diakses tanggal 23 Juni 2011]. Diunduh dari: http://www.fkmunair.ac.id.

14. Setyarini E. Faktor-faktor yang berhubungan dengan kejadian kanker leher rahim di RSUP Dr. Moewardi Surakarta. Surakarta: Fakultas Ilmu Kesehatan Universitas Muhammadiyah Surakarta; 2009.

15. Teheru E, Tjakraatmadja J. Penanggulangan kanker terpadu paripurna (PKRT) di wilayah DKI Jakarta. Majalah Ilmiah Fakultas Kedokteran Usakti. 1998; 17 (2).

16. Hidayati W. Kanker serviks displasia dapat disembuhkan. Jurnal Medika. 2001; XXVIII (3): 97.

17. Melva. Faktor-faktor yang mempengaruhi kejadian kanker leher rahim pada penderita yang datang berobat di RSUP H. Adam Malik Medan. [diakses tanggal 23 Juni 2011]. Diunduh dari: http://www.usu.ac.id. 
18. Dino A. Sunat, bermanfaat untuk kesehatan? 2006. Diunduh dari: http://groups.yahoo.com/group/keluarga-islam.

19. Zubairi D. Sirkumsisi/sunat efektif tekan penularan HIV. 2008. [diakses tanggal 12 Januari 2010]. Diunduh dari: http://www.koplemen.com.
20. Khasbiyah. Beberapa faktor risiko kanker serviks uteri (studi pada penderita kanker serviks uteri di Rumah Sakit Dr. Kariadi Semarang pada bulan agustus-september 2004). [diakses tanggal 23 Juni 2011]. Diunduh dari: http://www.fkm.undip.ac.id. 